\title{
Appropriate Methodology for Assessing the Economic Development Impacts of Wind Power
}

\author{
Introduction \\ Interest in wind power development is growing as a means of expanding local economies. Such \\ development holds promise as a provider of short-term employment during facility construction \\ and long-term employment from ongoing facility operation and maintenance. It may also support \\ some expansion of the local economy through ripple effects resulting from initial increases in \\ jobs and income. However, there is a need for a theoretically sound method for assessing the \\ economic impacts of wind power development.
}

These ripple effects stem from subsequent expenditures for goods and services made possible by first-round income from the development, and are expressed in terms of a multiplier. If the local economy offers a wide range of goods and services the resulting multiplier can be substantial - as much as three or four. If not, then much of the initial income will leave the local economy to buy goods and services from elsewhere. Loss of initial income to other locales is referred to as a leakage.

Northwest Economic Associates (NEA), under contract to the National Wind Coordinating Committee (NWCC), investigated three case study areas in the United States where wind power projects were recently developed. The full report, "Assessing the Economic Development Impacts of Wind Power," is available at NWCC's website http://www.nationalwind.org/. The methodology used for that study is summarized here in order to provide guidance for future studies of the economic impacts of other wind power developments. The methodology used in the NEA study was specifically designed for these particular case study areas; however, it can be generally applied to other areas. Significant differences in local economic conditions and the amount of goods and services that are purchased locally as opposed to imported from outside the will strongly influence results obtained. Listed below are some of the key tasks that interested parties should undertake to develop a reasonable picture of local economic impacts that may accrue from existing or future wind development.

\section{Identify Project Phases}

Wind power development results in local economic impacts during two different phases:

construction, which creates a one-time surge in economic activity, and operation and maintenance (O\&M), which makes an ongoing economic contribution by creating long-term jobs and continuing income streams. Both phases should be analyzed to offer a more complete picture of the economic benefits from a project.

\section{Identify Inputs}

In order to identify the effect that construction of a wind power project has on a local economy, it is necessary to identify the mix of inputs required to construct the project. A list of inputs would include dollars for turbines, dollars for wiring, and dollars for labor, and so on (see the highlight box for a list of ideal inputs for wind power development projects). To relate these inputs to the local economy, it is necessary to determine which inputs are obtained locally as opposed to inputs obtained from sources outside of the local area.

\section{Identify Sources of Inputs}


In general, many inputs needed for wind power projects are brought in from outside of the local area and do not affect the local economy. For instance, the purchase of turbines made in Europe and towers made in Louisiana for construction of a wind power project in Culberson County, Texas, will not affect the local (Culberson County) economy. Those inputs which are purchased from local sources will have the most effect on the local economy, and should therefore be the focus of data retrieval. An itemized list can be developed of components that are used in each phase of the projects, and inputs from local sources will have a direct effect on the economy. They are used to estimate the round by round multiplier effects and the effects on jobs and income through use of the input-output model.

\section{Approach Project Developer for Information and Interview Local Sources}

In an ideal situation, a list would be prepared of inputs actually used in constructing the project. Preferably, this information would come directly from the project developer, but this information is often proprietary and difficult to obtain. Researchers should first attempt to obtain this data from the project developer. When data on inputs for construction are not readily available, information can be obtained through interviews of potential suppliers in the local area. This information, combined with knowledge of the local economy, allows the estimation of what inputs are necessary, and which inputs can be obtained from local sources.

During NEA's research for the three case studies, the search for information focused on those activities likely providing the greatest opportunities for local inputs and local economic impacts, such as the construction of roads, tower foundations, and operations buildings. Because no records or other documentation of expenses actually incurred during construction were available for any of the study areas, local officials and potential input suppliers were contacted to obtain estimates of local inputs used. Local officials and potential suppliers were asked several questions, including:

- What were the nature and amounts of local inputs that were used in each study area?

- How many workers from the study area were employed?

- How many workers from outside the study area resided in the study area during construction?

- Where and on what goods did workers spent money locally?

Since this approach relied upon recall of events some time after they occurred, some items were no doubt overlooked, and impacts are understated to the degree this occurred in each study area.

\section{Estimate Direct, Indirect, and Induced Effects}

Using knowledge about local sources, and about the local economy, it is possible to identify those elements that have a direct effect on the local economy.

- A direct effect arises from the first round of buying and selling. In general, this is the purchase of some inputs, such as fuel, the spending of income earned by workers, annual landowner revenues, and the income effects of tax changes. These direct effects can be used to identify additional rounds of buying and selling for other sectors and to identify the effect on rounds of spending by local households.

- The indirect effect is the increase in sales of other industry sectors in the county, which includes further round by round sales.

- The induced effect is the increased household income expenditures generated by the direct and indirect output effects.

- The total effect is the sum of the direct, indirect, and induced effects. 
A relatively straightforward situation typically involves a single industry (e.g., a sawmill), which already exists in the study area and for which the value of new or additional output can be measured. The total value of the additional exports (change in final demand) can easily be calculated based on the quantity of new lumber output and value per unit. This change in final demand for the sawmill industry is entered into the model which estimates the impact on the rest of the economy. The direct effect is the change in final demand. The indirect effect is the increase in sales of other industry sectors in the county, such as logging contractors, forestry products, wholesale and retail trade, and electric services, which includes further round by round sales. The induced effect is the increased household income expenditures generated by the direct and indirect output effects.

The information about how the total output of the economy is affected by the round by round multiplier effect of the construction provides us with the basis for estimating the total effect of the construction on employment and income. A similar basis is used to estimate the effect of annual O\&M activities on the local economy.

\section{Use Established Economic Models to Estimate Effects}

NEA employed an input-output (I-O) model to measure the additional impact that the direct effects identified for the construction and O\&M phases have had on the local economy, in terms of additional industry output, employment, and income. The model is based on IMPLAN ("IMpact analysis for PLANning"), a system of software and data used to perform economic impact analysis. NEA used county-level IMPLAN data to develop models for each of the case study regions. The models were used to estimate the effects on the rest of the local economy of spending related to the initial construction and ongoing O\&M of the wind power developments. More detailed information on IMPLAN can be accessed in the full report.

(Note: While the producers of this report selected the IMPLAN model to estimate economic impacts, alternative input-output models could also be used.)

Impacts are generated within the models by estimating how final demand in the study areas will change as a result of some new economic activity (i.e., the direct effect of the economic activity). Estimating how this new economic activity results in a change to final demand is a key step in impact analysis.

More complex situations arise when the business is contained in an industry sector that is aggregated from dissimilar production technologies. This applies in the case of wind power, as wind power generation is included in the electric services industry, along with hydropower, coal and gas fired power generation, and nuclear power production. Even without a specific production function for wind power generation, the technology varies significantly among electricity generators represented in the IMPLAN electric services industry. Even if the value of output from a wind power project could be estimated, entering this value as a final demand change to the electric services industry could lead to misleading impact estimates. It is therefore necessary to use care in portraying the changes in final demand associated with wind power construction and O\&M.

For construction, the estimates of final demand changes include local expenditures made by labor for specific IMPLAN sectors, such as fuel, lodging, eating and drinking, or retail trade.

Construction inputs purchased from local suppliers are also estimated and entered as changes in final demand for these items. The effects on output, income, and employment are estimated in the model. 
For O\&M, much the same process is followed. The exception is that jobs in the electric services industry are located permanently in the local area. By entering an "expenditure pattern" for local O\&M expenses in the same manner as for construction these jobs are not picked up in the effects measured by the model. To adjust for this occurrence, these jobs in the electric services industry are estimated outside the model and added to the results estimated by the model. Land owner revenues and tax impacts are entered into the model as a change in local household spending, resulting in additional impacts within the local economy.

\title{
Consider Returns an Invested Capital
}

Another major input into O\&M for wind power projects is the return on the initial capital investment. For the three case study projects analyzed by NEA, all of the projects were owned by outside interests and very little if any of the capital investment was owned by local residents, so much of the return on capital investment left the local area. In other cases, the capital is supplied from local investors and the return on investment may provide significant local impacts. Such impacts should be considered for those projects where local investors play a significant role.

\section{Ideal List of Input for Wind Power Development Projects (to be placed in a highlight box)}

\author{
Construction Costs \\ Materials \\ Construction (concrete rebar, equip, roads and site prep) \\ Transformer \\ Electrical (drop cable, wire, ) \\ HV line extension \\ Subtotal \\ Labor \\ Foundation \\ Erection \\ Electrical \\ Management/supervision \\ Subtotal \\ Subtotal
}

\section{Equipment Costs}

Turbines (excluding blades and towers)

Blades

Towers

Subtotal

\section{Other Costs}

HV Sub/Interconnection

Engineering

Legal Services

Land Easements

Site Certificate/Permitting

Subtotal

\section{Total}




\author{
Wind Plant Annual Operating and Maintenance Costs \\ Personnel \\ Field Salaries \\ Adminstrative \\ Manangement \\ Subtotal \\ Materials and Services \\ Vehicles \\ Misc. Services \\ Fees, Permits, Licenses \\ Utilities \\ Insurance \\ Fuel (motor vehicle gasoline) \\ Tools and Misc. Supplies \\ Spare Parts Inventory \\ Subtotal \\ Financing (avg ann debt payment) \\ Equity Payment - Individuals (avg ann payment) \\ Equity Payment - Corporations (avg ann payment) \\ Land Lease \\ Total
}

